\title{
Praktek Manajemen Sumber Daya Manusia Berbasis Kompetensi pada Organisasi Sektor Publik
}

\author{
Alfian Rosiadi*, Margono Setiawan, Wahdiyat Moko \\ Fakultas Ekonomi dan Bisnis Universitas Brawijaya, Malang \\ *alfian.rosiadi@gmail.com
}

\begin{abstract}
This study aims to explore human resource management practice based on competency in public sector organizations by taking case studies at the Government of Tulungagung Regency. The human resource management practice based on competency in public sector organizations have been conducted through the application of Law no. 5/2014 about the State Civil Apparatus. This study uses a qualitative approach where data obtained through semi-structured in-depth interviews of 7 (seven) research informants which authorized in public sector human resource management. The results of data analysis shows that the implementation of human resources management practice based on competency is found in the recruitment and selection process, career management and competency development. But human resources management practice on competency is not found in the performance appraisal.
\end{abstract}

Keywords: Competence, Human Resource Management, Local Government, Public Sector.

\section{PENDAHULUAN}

Di negara-negara yang berkembang organisasi sektor publik memiliki peranan yang signifikan dalam kehidupan ekonomi masyarakat. Organisasi sektor publik memiliki keunggulan yang kadang tidak dimiliki oleh organisasi swasta yaitu kemampuannya dalam memproduksi barang dan jasa yang menjadi kebutuhan dasar masyarakat. Dari sudut pandang ekonomi, organisasi sektor publik mampu memberikan kontribusi terhadap pertumbuhan ekonomi yang mampu mencapai kurang lebih 20-30\% dari Gross Domestic Product (Arundel, Casali, \& Hollanders, 2015; Bingle, Meyer, \& Taylor, 2013) serta menyerap $17-22 \%$ tenaga kerja di negara-negara barat seperti Amerika Serikat dan Eropa (Burdett, 2011; Darling \& Cunningham, 2016). Selain itu, kinerja organisasi sektor publik juga dianggap mencerminkan tingkat kemajuan suatu negara dan faktor utama yang mampu menumbuhkan kepercayaan masyarakat kepada pemerintah (Moeheriono, 2014).

Peran besar yang dimiliki organisasi sektor publik dalam kehidupan suatu masyarakat atau negara, sayangnya seringkali tidak diimbangi dengan kualitas atau kinerja organisasi sektor publik itu sendiri. Selain dikenal sebagai organisasi yang terlalu konservatif dan birokratis (Bloch \& Bugge, 2013), serta cenderung bersifat menghindari adanya resiko (Buurman, Delfgaaue, Dur, \& Bossche, 2012), organisasi sektor publik selama ini juga lekat dengan stigma inefisien, tidak efektif, boros dan kurang mampu mengadaptasi perubahan teknologi (Androniceanu, 2007; Kapucu, 2009; Philippidou, Soderquist, \& Prastacos, 2004; Scharitzer \& Korunka, 2000; Siugzdiniene, 
2006) dan koruptif (Sukmadilaga, Pratama, \& Mulyani, 2015). Kondisi tersebut telah melatarbelakangi adanya upaya dan tuntutan untuk melakukan reformasi organisasi sektor publik yang melanda di seluruh dunia.

Salah satu titik fokus reformasi birokrasi adalah perubahan dan perbaikan sumber daya manusia sektor publik (Antwi \& Analoui, 2008; Common, 2011; Khan \& Charles-Soverall, 1993; Shen, Zhong, \& Chen, 2016). Di masa lalu, sumber daya manusia sektor publik sangat lekat dengan stigma incompetent dan uncapable. Betapapun sempurnanya konsep reformasi birokrasi, tanpa adanya reformasi manajemen sumber daya manusia (MSDM) sektor publik, maka upaya reformasi birokrasi akan berlangsung sia-sia.

Menteri Pendayagunaan Aparatur Negara dan Reformasi Birokrasi (MenPANRB) Asman Abrur, pada tahun 2016 pernah menyampaikan bahwa terdapat 64 persen Pegawai Negeri Sipil (PNS) yang kualitasnya di bawah standar (-, 2016a) dimana hal ini serupa dengan yang disampaikan oleh Thoha (2016) yang menyampaikan bahwa PNS yang kompeten dan produktif jumlahnya hanya sekitar 40\% (Thoha, 2016). Hal ini diperparah dengan gap kompetensi PNS yang jauh antara tingkat pendidikan dan kemampuan PNS dalam melaksanakan tugasnya, rendahnya kesadaran badan kepegawaian dalam pengembangan kompetensi PNS, serta kurang optimalnya pelaksanaan desentralisasi pengembangan kompetensi PNS (-, 2016b). Dampak dari rendahnya kompetensi PNS ini adalah rendahnya kinerja yang dihasilkan oleh instansi pemerintah (Rochmi, 2017) (Rochmi, 2017).

Upaya perbaikan kualitas PNS sebenarnya telah didukung dengan diterbitkannya Undang-Undang Nomor 5 Tahun 2014 tentang Aparatur Sipil Negara (ASN). Undang-undang ini dianggap mentransformasikan Manajemen SDM sektor publik di Indonesia ke dalam manajemen berbasis sistem merit (Indonesia, 2014a), dan bahkan menuju kepada human capital management (Sensuse, Cahyaningsih, \& Wibowo, 2015). Regulasi ini secara spesifik dilanjutkan dengan diberlakukannya Peraturan Pemerintah (PP) Nomor 11 Tahun 2017 tentang Manajemen Pegawai Negeri Sipil (PNS) pada awal tahun 2017. Mohammad Ridwan, Kepala Biro Humas Badan kepegawaian Negara (BKN) menyebutkan bahwa PP ini membawa sistem manajemen PNS yang berdasarkan kualifikasi, kompetensi dan kinerja (-, 2017; Indonesia, 2017). Di era sebelumnya, standar kompetensi hanya dikhususkan dan dipersyaratkan bagi PNS yang akan menduduki jabatan struktural, sedangkan manajemen PNS secara menyeluruh lebih didasarkan kepada senioritas melalui sistem kepangkatan. Dengan diterbitkannya UU Nomor Tahun 2014 tentang ASN dan PP nomor 11 tahun 2017 menggiring penerapan manajemen SDM berbasis kompetensi dalam manajemen PNS.

\section{Manajemen SDM Sektor Publik}

Sebelum reformasi birokrasi, sistem administrasi publik tradisional seringkali "menjebak" seseorang dengan kemampuan yang bagus di dalam sistem manajemen yang buruk (Shen et al., 2016). Hal ini seringkali tampak pada sistem pengembangan karir dalam organisasi sektor publik yang cenderung mengedepankan aspek senioritas dan masa kerja daripada kinerja. Keadaan ini menjadikan seseorang dengan potensi dan kinerja yang tinggi tidak dapat menempati posisi atau jabatan yang sesuai dengan kapabilitasnya.

Bagi negara-negara yang ingin melakukan reformasi organisasi sektor publiknya, pengembangan dan manajemen sumber daya manusia (MSDM) menempati posisi yang krusial bersama dengan konsep desentralisasi (Antwi \& Analoui, 2008; Setiyono, 2014; Shen et al., 2016). Kinerja dan kapabillitas organisasi sektor publik ditentukan juga dari kemampuan sumber daya manusianya. Hal ini sejalan dengan pendapat bahwa kualitas suatu organisasi sektor publik sangat tergantung dari kualitas sumber daya manusia yang dimilikinya (Chau, 1997). Sumber daya manusia yang handal juga dapat dimanfaatkan dalam meraih keunggulan 
kompetitif organisasi (Jackson, Schuler, \& Werner, 2009). Kondisi ini menjadikan manajemen sumber daya manusia sektor publik mengalami perubahan peranan yang cukup signifikan dengan munculnya paradigma reformasi birokrasi. OECD (1996) menyebutkan bahwa Manajemen sumber daya manusia pada organisasi sektor publik harus menjadi bagian dari manajemen strategik (Hondeghem \& Vandermeulen, 2000).

Berbagai masalah seringkali dihadapi oleh MSDM pada organisasi sektor publik. Masalah yang sering dihadapi dalam sistem MSDM birokrasi tradisional adalah: 1) struktur hierarki menyebabkan organisasi menjadi tidak fleksibel dalam menghadapi perubahan; 2) pengangkatan pegawai yang berlaku seumur hidup dan skema pensiun tanpa evaluasi menyebabkan pegawai cenderung bekerja seenaknya saja; 3) prinsip senioritas menyebabkan potensi pegawaipegawai muda menjadi tidak teraktualisasikan secara optimal; dan 4) sistem pembinaan personel yang cenderung subjektif (Setiyono, 2014).

\section{Kompetensi}

Saleh et al. (2013) menyebutkan kompetensi sebagai kecakapan, kemampuan dan kewenangan yang berasal dari kata dalam bahasa inggris "competent" (adj.). Sedangkan secara terminologis, meskipun terdapat beberapa perbedaan pendapat mengenai frasa yaitu "competent", "competency" dan "competencies", kesemuanya mengacu kepada kemampuan atau kapabilitas seseorang (termasuk perilaku individu yang bersangkutan) dalam melaksanakn tugas dan tanggung jawabnya (Saleh, Islamy, Zauhar, \& Supriyono, 2013). Pendapat ini serupa dengan yang disampaikan oleh Jackson et al. (2009), bahwa kompetensi merupakan pola pengetahuan, ketrampilan, kemampuan, perilaku dan karakteristik lainnya yang bisa diukur dan dibutuhkan untuk melakukan pekerjaan dengan baik (Jackson et al., 2009). Pendapat lain mengemukakan bahwa kompetensi individu terdiri dari skill, knowledge, attitude dan value yang dapat menghasilkan kinerja maksimal (Audenaert, Vanderstraeten, Buyens, \& Desmidt, 2014). Faktor pengalaman yang dibutuhkan juga ditambahkan sebagai bagian yang membentuk suatu kompetensi (Azis \& Akhtar, 2014). Moqvist (2002) yang menyebutkan bahwa kompetensi tediri dari 5 (lima) jenis dimensi yang berbeda yaitu psikomotorik, kognitif, afektif, personality, dan sosial yang menurut Brans dan Hondeghem (2005) dapat dikelompokkan menjadi 2 (dua) kelompok besar yaitu hard competency dan soft competency atau generic competency dan specific competency (Azmi, 2010). Sementara pendapat yang paling sering dirujuk adalah definisi kompetensi menurut Spencer dan Spencer (1993) yang menyebutkan kompetensi adalah "an underlying characteristic of an individual that is casually related to criterion referenced effective and/or superior performance in a job or situation" (Spencer \& Spencer, 1993).

Dessler (2015) menekankan bahwa kompetensi yang terdiri dari knowledge, skill dan attitude, haruslah dapat diamati dan diukur (Dessler, 2015). Mengenai hal ini Spencer dan Spencer (1993) yang menyatakan bahwa dimensi skill dan knowledge adalah dua dimensi kompetensi yang lebih visible (terlihat, mudah diukur dan dikembangkan) sedangkan dimensi lainnya, yang berkaitan dengan karakteristik pribadi seseorang cenderung bersifat more difficult to develop dan tersembunyi sebagaimana gambar 1 berikut :

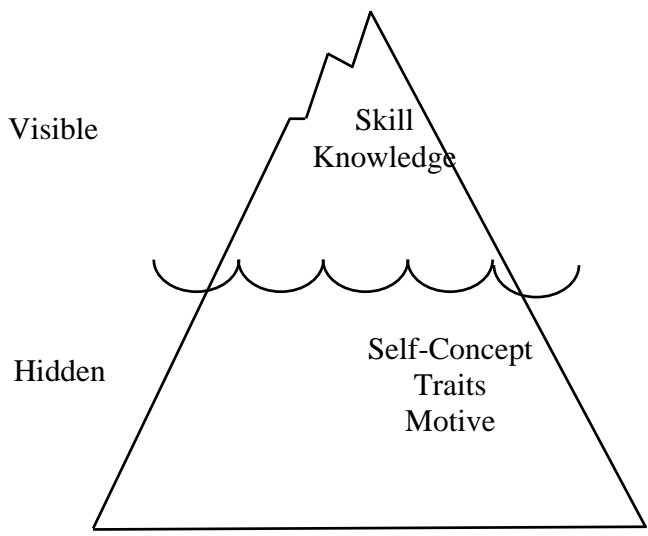

Gambar 1. The Iceberg Model (Spencer \& Spencer, 1993) 
Dari pendapat-pendapat di atas, dapat ditarik kesimpulan bahwa kompetensi adalah karakteristik dasar yang dapat diamati, diukur dan dikembangkan di dalam diri seorang individu yang bermanfaat untuk meraih kinerja yang maksimal dan sekurangkurangnya terdiri atas dimensi pengetahuan (knowledge), ketrampilan (skill) dan karakteristik pribadi (personal characteristic).

\section{Manajemen SDM Berbasis Kompetensi}

Pendekatan kompetensi dalam MSDM telah dikenal sejak lama. Konsep kompetensi diketahui telah dikembangkan sejak jaman kekaisaran Romawi dan China sebelum kembali dikembangkan oleh McClelland dalam aktivitas seleksi (Akbar \& Akbar, 2012). Manajemen SDM berbasis kompetensi adalah penggunaan model kompetensi dalam pelaksanaan praktek-praktek MSDM, di antaranya rekrutmen dan seleksi, pelatihan dan pengembangan, penilaian kinerja, remunerasi dan proses MSDM lainnya (Audenaert et al., 2014; Azmi, 2010). Sementara pendapat lain mengutarakan MSDM berbasis kompetensi berkaitan dengan proses pengambilan keputusan dalam MSDM yang berdasarkan pada informasi kompetensi (Sedarmayanti, 2016). Hal ini menyebabkan pergeseran proses MSDM menjadi lebih individual oriented daripada pendekatan MSDM tradisional, dan merubah sudut pandang dari deskripsi pekerjaan menjadi fungsi / peranan karyawan dalam pekerjaan mereka. Bagi karyawan, MSDM berbasis kompetensi mampu memberikan informasi mengenai keterampilan yang harus dikembangkan untuk bisa memenuhi syarat dari pekerjaan tertentu (Jackson et al., 2009). Moeheriono (2014) memaparkan konsep MSDM berbasis kompetensi sebagai berikut :

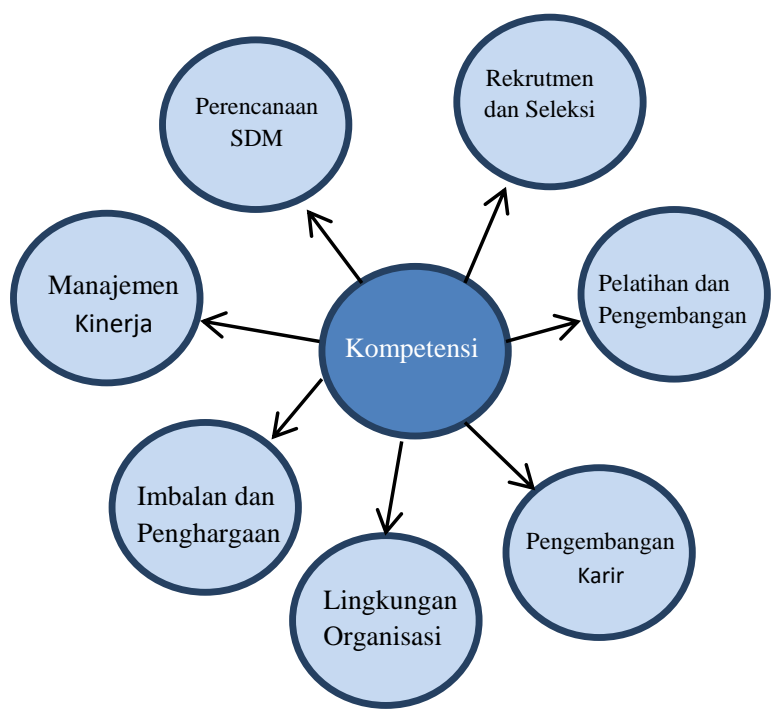

Gambar 2. Konsep MSDM berbasis Kompetensi (Moeheriono, 2014)

Dari paparan di atas juga dapat disimpulkan bahwa MSDM berbasis kompetensi bermanfaat dalam aktivitas MSDM, di antaranya: 1) meningkatkan efektivitas organisasi melalui pengangkatan individu-individu pada jabatan yang sesuai dengan kompetensinya; 2) memperjelas pola karier dan pengembangan karier karyawan, karena dengan adanya standar kompetensi jabatan, individu yang ingin mengembangkan kariernya dapat mengetahui apa saja yang harus dia capai untuk meraih jabatan tersebut; 3) meningkatkan efisiensi dan efektivitas program pengembangan kompetensi yang sesuai dengan kebutuhan organisasi dan pengembangan karier karyawan; 4) dapat memberikan reward yang adil dan proporsional sesuai dengan kinerja masingmasing; 5) memberikan suasana kerja yang sehat dan kompetitif melalui penilaian kompetensi dan kinerja yang fair.

\section{METODE}

Penggunaan pendekatan kualitatif diharapkan mampu memberikan pemahaman yang lebih mendetail mengenai fenomena yang diteliti pada penelitian ini. Creswell (2014) menyampaikan bahwa penelitian kualitatif adalah merupakan metode-metode untuk mengeksplorasi dan memahami makna yang dianggap berasal dari masalah sosial atau kemanusiaan melalui prosedur 
pengumpulan data yang spesifik, analisis data induktif, menafsirkan makna data, serta menerapkan cara pandang yang bergaya induktif, fokus pada makna individual dan kompleksitas suatu persoalan, dengan hasil laporan akhir yang fleksibel (Creswell, 2014).

Pendekatan studi kasus dilakukan untuk memperoleh pemahaman mengenai pelaksanaan manajemen SDM berbasis kompetensi pada organisasi sektor publik yang belakangan menjadi perhatian khusus para pemangku kepentingan untuk meningkatkan kinerja dari organisasi sektor publik.

Fokus dari penelitian ini adalah terkait implementasi MSDM berbasis kompetensi dalam manajemen PNS pada Pemerintah Kabupaten Tulungagung, sehingga pengambilan data penelitian dilakukan di Kabupaten Tulungagung yang berada di Provinsi Jawa Timur. Pemilihan lokasi penelitian didasari kondisi bahwa Pemerintah Kabupaten Tulungagung sebagai salah satu organisasi sektor publik di Indonesia, telah memiliki berbagai capaian kinerja yang memuaskan dalam beberapa tahun terakhir. Oleh karena itu penting untuk mengetahui bagaimana pengelolaan kompetensi sumber daya manusia dalam manajemen PNS pada Pemerintah Kabupaten Tulungagung yang telah mampu membawa Pemerintah Kabupaten Tulungagung meraih capaian kinerja yang memuaskan.

Maykut dan Morehouse (1994) menyampaikan bahwa cara yang paling berguna dalam mengumpulkan data pada penelitian kualitatif adalah obervasi, wawancara mendalam, wawancara kelompok, dan pengumpulan dokumendokumen yang relevan (Ridder \& Hoon, 2009; Wahyuni, 2012). Penelitian ini menggunakan teknik wawancara sebagai metode utama dalam mengumpulkan data.

Wawancara yang dilakukan pada penelitian ini adalah wawancara mendalam (in depth interview) dengan metode semistructured interviews (wawancara semi terstruktur). Wawancara semi terstruktur dilakukan dengan cara mewawancarai secara langsung dan mendalam dengan pertanyaan- pertanyaan yang telah disiapkan melalui panduan wawancara dan pertanyaanpertanyaan spontan yang dikembangkan berdasarkan jawaban yang diberikan informan atau situasi yang ada di lapangan, kepada pihak yang terlibat dan terkait langsung guna mendapatkan penjelasan yang lebih mendalam tentang kondisi dan situasi yang sebenarnya.

Pada penelitian ini pemilihan informan menggunakan metode purposive sampling dan dipadukan dengan metode snowball sampling. Wawancara dilakukan pada rentang waktu Februari-Maret 2018, dengan informan para pelaksana dan pejabat di bidang kepegawaian pada Pemerintah Kabupaten Tulungagung. Adapun key informan pada penelitian ini adalah :

Tabel 1. Informan Penelitian

\begin{tabular}{|c|c|c|}
\hline No & $\begin{array}{c}\text { Nama } \\
\text { Informan }\end{array}$ & Jabatan \\
\hline 1 & DEP & $\begin{array}{l}\text { Kepala Sub Bidang Diklat } \\
\text { Teknis Fungsional } \\
\text { Aparatur, 2008-2015 }\end{array}$ \\
\hline 2 & $\mathrm{CH}$ & $\begin{array}{l}\text { Kepala Bidang Pengadaan } \\
\text { dan Pembinaan ASN } \\
\text { Badan Kepegawaian } \\
\text { Daerah, 2017-sekarang }\end{array}$ \\
\hline 3 & $\mathrm{JU}$ & $\begin{array}{l}\text { Kepala Sub Bidang } \\
\text { Mutasi Badan } \\
\text { Kepegawaian Daerah, } \\
\text { 2014-sekarang }\end{array}$ \\
\hline 4 & $\mathrm{AM}$ & $\begin{array}{l}\text { Kepala Seksi Diklat } \\
\text { Penunjang dan Sertifikasi } \\
\text { Badan Kepegawaian } \\
\text { Daerah, 2015-sekarang }\end{array}$ \\
\hline 5 & $\mathrm{EC}$ & $\begin{array}{l}\text { Pelaksana Kepegawaian } \\
\text { Dinas Pekerjaan Umum } \\
\text { dan Penataan Ruang, } \\
\text { 2009-sekarang }\end{array}$ \\
\hline 6 & IKR & $\begin{array}{l}\text { Kepala Badan } \\
\text { Kepegawaian Daerah, } \\
\text { 2014-2017 }\end{array}$ \\
\hline 7 & $\mathrm{ST}$ & $\begin{array}{l}\text { Sekretaris Badan } \\
\text { Perencanaan } \\
\text { Pembangunan Daerah, } \\
\text { 2017-sekarang }\end{array}$ \\
\hline
\end{tabular}

Metode selanjutnya adalah metode dokumentasi. Pemilihan metode ini didasari oleh aktivitas organisasi sektor publik yang 
banyak ditentukan oleh regulasi, legislasi, politik dan kebutuhan sosial (Common, 2011). Metode dokumentasi dilakukan dengan membaca, mempelajari dan mengkaji berbagai dokumen peraturan perundangundangan, data-data kepegawaian, dan dokumen-dokumen lain yang terkait dengan manajemen PNS yang diperoleh selain dari informan penelitian, juga dari website instansi pemerintah.

Data yang diperoleh kemudian dianalisis melalui lima fase teknik analisis data seperti yang terlihat pada gambar dibawah ini:

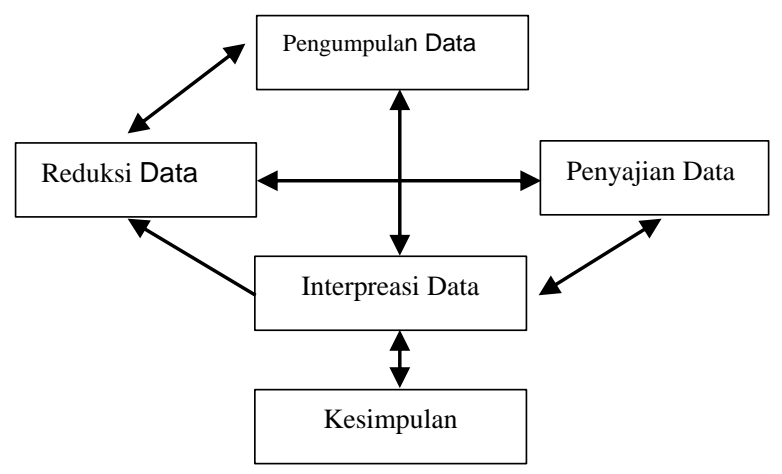

Gambar 3. Teknik Analisis Data Yin (2011)

Tahapan pertama adalah pengumpulan data dari lapangan dimana apabila data yang diperlukan belum mencukupi maka dapat menambahkan dengan menambah informan sampai data dirasa cukup. Tahap kedua yaitu proses reduksi kumpulan-kumpulan data menjadi bagian-bagian yang lebih kecil untuk mempertegas, menitikberatkan, membuang hal-hal yang tidak penting sehingga peneliti dapat menarik kesimpulan dengan mudah. Proses reduksi data dapat dilakukan berulang kali. Tahap ketiga adalah penyajian data dimana dalam tahapan ini dilakukan pengorganisasian informasi secara sistematis, penggabungan dan merangkai keterkaitan antar data, menggambarkan proses serta fenomena yang ada di objek penelitian. Tahap keempat ialah proses penyajian data sehingga peneliti dapat mengginterpretasikan data yang diperoleh dalam proses penelitian. Tahap kelima merupakan tahapan penutup. Tahapan ini adalah penggambaran kesimpulan dari keseluruhan penelitian, kesimpulan ini terkait dengan interpretasi dari tahap keempat serta mencakup semua tahapan yang lainnya (Yin, 2011).

\section{HASIL DAN PEMBAHASAN \\ Rekrutmen dan Seleksi}

Pemerintah Kabupaten Tulungagung termasuk salah satu Pemerintah Daerah yang terkena kebijakan moratorium PNS. Hal ini disebabkan oleh beban belanja pegawai yang lebih dari 50\% dari total Anggaran Pendapatan dan Belanja Daerah (APBD). Kondisi ini menyebabkan sejak tahun 2012 Pemerintah Kabupaten Tulungagung tidak pernah mengadakan proses rekrutmen dan seleksi CPNS dan menjadikan keterbatasan dalam penelitian ini. Akan tetapi setiap tahunnya pemerintah Kabupaten Tulungagung tetap menyampaikan kebutuhan PNS (formasi) ke kementeria PAN-RB dan menyiapkan segala sesuatu apabila diijinkan untuk melaksanakan rekrutmen dan seleksi CPNS.

Tahapan seleksi CPNS yang dilakukan oleh Pemerintah Kabupaten Tulungagung pun disusun sebagaimana amanah UU ASN dan PP Manajemen PNS. Tahapan proses rekrutmen dan seleksi CPNS ini meliputi: 1) perencanaan, 2) pengumuman lowongan, 3) proses pelamaran, 4) seleksi, 5) pengumuman hasil seleksi, 6) pengangkatan CPNS dan masa percobaan CPNS, dan 7) pengangkatan menjadi PNS. Proses seleksi yang dilakukan sebagaimana yang termuat dalam PP Manajemen PNS, dilakukan dalam 2 (dua) tahapan, yaitu Seleksi Kompetensi Dasar (SKD) dan Seleksi Kompetensi Bidang (SKB). Dalam proses ini materi soal ujian dan sebagainya menjadi kewenangan dari Panitia Seleksi Nasional (Panselnas), dimana pemerintah daerah dalam hal ini BKD hanya bertindak sebagai fasilitator. Pemerintah daerah bahkan tidak dapat melakukan intervensi terhadap hasil SKB, SKD maupun hasil seleksi secara komprehensif. Hal ini sebagaimana dinyatakan oleh Bapak $\mathrm{CH}$ berikut :

"Proses pengadaan dilakukan oleh Panselnas, jadi melalui tim yang dibentuk 
oleh pemerintah pusat, kami yang di daerah hanya bertugas melaksanakan proses seleksi saja, seperti fasilitator. Proses seleksi sendiri dilakukan melalui metode Computer Assesment Test (CAT), dimana soal dan hasil seleksi menjadi kewenangan penuh pemerintah pusat."

Proses rekrutmen dan seleksi adalah sebuah proses untuk menemukan dan atau menarik kandidat karyawan ke dalam suatu posisi kerja (Dessler, 2015). Sedarmayanti (2016) berpendapat bahwa seleksi adalah kegiatan menentukan dan memilih tenaga kerja yang memenuhi kriteria yang telah ditetapkan (Sedarmayanti, 2016). MSDM berbasis kompetensi dalam proses rekrutmen dan seleksi didefinisikan sebagai sebuah metode untuk melakukan pemilihan kandidat secara tepat dan efektif melalui penilaian kesesuaian kompetensi yang dibutuhkan oleh perusahaan untuk meraih tujuan dan visi misi organisasi dengan kompetensi yang dimiliki oleh pelamar (Azmi, 2010). Hal ini sesuai pendapat Chan (2006) dimana calon karyawan harus menunjukkan kompetensi yang sesuai dengan kompetensi inti organisasi (Chan, 2006).

Proses rekrutmen dan seleksi (yang terkait secara langsung dengan aktivitas perencanaan SDM) secara normatif telah memenuhi prinsip-prinsip MSDM berbasis kompetensi yang dibuktikan dengan adanya seleksi kompetensi dasar, seleksi kompetensi bidang dan seleksi lain (seperti tes kesehatan, psikotes dan tes lain apabila diperlukan) dimana kompetensi menjadi syarat utama yang menentukan lolos tidaknya seorang pelamar menjadi CPNS, terutama dengan adanya seleksi kompetensi bidang yang mengukur kesesuaian kompetensi pelamar dengan tugas jabatan yang akan dilamarnya. Akan tetapi karena belum pernah dilakukannya proses rekrutmen dan seleksi PNS di Pemerintah Kabupaten Tulungagung, sulit untuk melihat kelebihan maupun kelemahan atau kekurangan dalam proses rekrutmen dan seleksi ini utamanya dalam konteks pelaksanaan MSDM berbasis kompetensi.

\section{Pelatihan dan Pengembangan}

Pengembangan kompetensi yang dilakukan oleh pemerintah Kabupaten Tulungagung dilakukan melalui pendidikan dan pelatihan, baik diklat formal maupun non formal. Diklat formal dilakukan melalui pemberian ijin belajar dan tugas belajar, sedangkan diklat non formal melalui pelaksanaan diklat manajerial, diklat teknis dan fungsi.

Hambatan yang terjadi dalam pelaksanaan program pelatihan dan pengembangan adalah masih belum dipahaminya makna pengembangan kompetensi oleh PNS. Sebagian hanya menganggap program diklat syarat formalitas atau sebagai kewajiban semata, Bapak DEP menjelaskan sebagai berikut:

"Misalkan diklat. Untuk pejabat struktural diwajibkan mengikuti diklat kepemimpinan, akan tetapi peserta diklat sendiri banyak yang menganggap diklat itu sekedar kewajiban bukan kebutuhan. Istilahnya mungkin mereka sekedar menggugurkan kewajiban."

Para pemangku kepentingan terkait manajemen SDM organisasi sektor publik sebetulnya menyadari akan pentingnya suatu kegiatan pengembangan kompetensi, akan tetapi hambatan-hambatan berupa ketersediaan anggaran dan infrastruktur menjadi sebuah kendala yang kadang menyebabkan pelaksanaan program pengembangan kompetensi menjadi kurang berjalan baik, hal ini dijelaskan secara detail oleh Bapak AM berikut ini:

"kalau kebutuhan, sebenarnya kita, seluruh pejabat eselon akan didiklatkan, terbentur hal-hal yang, anggaran, tempat, jadi kita menunggu badan diklat yang ada di surabaya, jogja, untuk mengirimkan"

Selain biaya dan infrastruktur, kondisi di dalam internal organisasi juga dapat 
menjadi penghambat. Pelaksanaan program diklat yang menyebabkan PNS harus meninggalkan pekerjaan sehari-harinya seringkali menyebabkan pimpinan unit organisasi tidak memberikan ijin bagi seorang PNS untuk mengikuti diklat. Kondisi ini digambarkan oleh Bapak EC berikut ini:

"pimpinan terkadang tidak mengijinkan yang bersangkutan untuk mengikuti diklat, mungkin karena selain biaya, masih dibutuhkan tenaganya untuk menyelesaikan tugas"

Program pengembangan kompetensi karyawan melalui pendidikan dan pelatihan menjadi bagian yang penting dalam MSDM untuk mengejar ketertinggalan dan mempersempit gap kompetensi yang ada. Robbins dan Judge (2015) bahkan menyebutkan karyawan lama yang sebelumnya memiliki kompetensi bagus, tidak selamanya tetap memiliki kompetensi yang bagus, karena keahlian-keahlian baru akan selalu muncul untuk dipelajari (Robbins \& Judge, 2015). MSDM berbasis kompetensi dalam pelatihan dan pengembangan karyawan memiliki arti sebagai suatu upaya untuk menutup celah (gap) yang ada antara kompetensi yang dimiliki karyawan dengan kompetensi yang diinginkan oleh organisasi sesuai dengan profil pekerjaan (Azmi, 2010). MSDM berbasis kompetensi dalam proses pelatihan dan pengembangan menekankan pentingnya apa yang dapat dilakukan seseorang sebagai hasil pelatihan (output) daripada pendekatan tradisional yang lebih mementingkan aspek kehadiran dalam pelatihan (input). Praktek MSDM berbasis kompetensi dalam pelatihan dan pengembangan ditunjukkan melalui, pertama adanya analisis kebutuhan program pelatihan dan pengembangan yang tepat, kedua terdapat manfaat dari program pelatihan bagi pengembangan karier individu, dan ketiga adanya evaluasi terhadap pelaksanaan program pengembangan dan pelatihan terhadap pengembangan kompetensi individu. Dari ketiga aspek ini, aspek pertama terkendala oleh ketiadaan dukungan infrastruktur dan biaya (anggaran) serta kurangnya dukungan dari pimpinan unit organisasi sehingga tidak dapat dilakukan dengan baik. Aspek kedua dapat dilaksanakan sebagian, dimana keikutsertaan dalam program pengembangan pelatihan menjadi syarat dalam pengembangan karir seorang PNS baik dalam promosi dan mutasi meskipun beberapa oknum PNS masih menganggap diklat sebagai kegiatan formalitas. Sedangkan aspek ketiga belum dapat dilaksanakan karena tidak adanya uji kompetensi yang komprehensif, tidak adanya sistem pengukuran kinerja yang efektif bagi PNS yang telah mengikuti diklat.

\section{Manajemen Karir}

Manajemen karir didefinisikan sebagai sebuah proses yang memungkinkan karyawan untuk lebih memahami dan mengembangkan ketrampilan dan minat karier mereka, dan untuk menggunakan ketrampilan dan minat ini secara lebih efektif (Dessler, 2015). MSDM berbasis kompetensi dalam manajemen karir didefinisikan sebagai upaya untuk pengembangan dan peningkatan kinerja karyawan melalui sebuah pola karir yang sesuai antara kompetensi yang dimiliki oleh karyawan dengan profil kompetensi jabatan (Azmi, 2010). MSDM berbasis kompetensi bertujuan untuk menghindari adanya kemungkinan kinerja yang tidak optimal sebagai akibat tidak dapat dimanfaatkannya kompetensi yang dimiliki oleh seorang karyawan karena berada pada tugas dan jabatan yang tidak tepat. Selain itu, MSDM berbasis kompetensi akan membuat jalur karier menjadi cukup jelas, dan dapat membantu karyawan untuk menentukan tingkat kinerja yang harus dicapai untuk bisa mendapatkan kenaikan pangkat (Jackson et al., 2009).

Proses manajemen karir ditunjukkan melalui aktivitas promosi dan mutasi dimana proses yang menentukan dalam promosi dan mutasi adalah uji kompetensi. Keberadaan uji kompetensi ini menunjukkan bahwa prinsipprinsip MSDM berbasis kompetensi telah dilakukan dalam proses promosi dan mutasi. Pada saat penelitian ini dilakukan, uji 
kompetensi masih sebatas dilakukan pada calon pejabat JPT dan akan dilakukan pada jabatan administrator atau eselon III. Keterbatasan anggaran menjadi kendala dalam pelaksanaan uji kompetensi ini. Uji kompetensi yang telah dilakukan masih menggunakan dana bantuan dari APBN. Akan tetapi Pemerintah Kabupaten Tulungagung melalui BKD memiliki komitmen untuk melaksanakan uji kompetensi secara menyeluruh kepada seluruh PNS. Hal ini dilakukan karena disadari, bahwa uji kompetensi merupakan awal dari pelaksanaan manajemen PNS berdasarkan kualifikasi, kompetensi dan kinerja sebagaimana amanat UU ASN.

Tantangan yang dihadapi oleh BKD selaku perangkat daerah yang bertanggunngjawab terhadap pelaksanaan manajemen PNS, dalam pelaksanaan uji kompetensi adalah masih munculnya persepsi bahwa hasil uji kompetensi dalam seleksi terbuka dapat dipolitisasi. Sebenarnya hal ini tidak lepas dari "celah" yang diberikan oleh UU ASN dimana hasil seleksi terbuka memunculkan 3 (tiga) kandidat terbaik. Pemilihan satu di antara 3 kandidat ini menjadi hak sepenuhnya dari kepala daerah. Untuk itu perlu komitmen tinggi dari PPK (Pejabat Pembina Kepegawaian yang dijabat oleh Kepala Daerah) dan PyB (Pejabat yang Berwenang, dijabat oleh Sekretaris Daerah, PNS dengan tingkat jabatan tertinggi dalam organisasi pemerintah daerah) untuk menunjukkan bahwa hasil seleksi terbuka merupakan sebuah hasil yang akurat dan kredibel.

Untuk menjamin obyektifitas uji kompetensi dalam seleksi terbuka, dalam pembentukan anggota panitia seleksi terbuka didominasi oleh pihak eksternal (akademisi, ahli dan profesional), selain itu rekomendasi dari KASN dalam setiap tahapan juga menjadi acuan. Dalam uji kompetensi materi yang diujikan menyangkut ketrampilan dalam manajemen pemerintahan dan kemampuan analisis terhadap permasalahan yang mungkin dihadapi. Tetapi, aspek karakteristik dan kepribadian peserta masih belum dilakukan penilaian.
Dalam proses promosi dan mutasi pada level di bawah JPT, pemenuhan terhadap syarat regulasi masih menjadi acuan utama. Hal ini disebabkan uji kompetensi belum dilakukan serta sistem kepangkatan yang masih dipergunakan sampai terbit aturan baru mengenai kepangkatan. Kemudian rekomendasi dari atasan memegang peranan penting. Hal ini sebagai dampak belum adanya informasi kompetensi dan kinerja yang memadai. Akibat buruk yang mungkin dimunculkan dalam hal ini, adalah kemungkin pimpinan lebih mengedepankan aspek subyektifitas daripada kompetensi seseorang.

Resistensi terhadap pelaksanaan prinsip MSDM berbasis kompetensi di Pemerintah Kabupaten Tulungagung yang muncul kemudian adalah adanya ego sektoral dari pimpinan. Sering terjadi pimpinan tidak mengusulkan seorang PNS yang telah memenuhi syarat dan memiliki kompetensi dan kinerja yang bagus untuk mendapatkan promosi karena takut apabila PNS tersebut dipromosikan di luar perangkat daerah yang dia pimpin. Pemikiran seperti ini tentu dapat menghambat karier dan pengembangan kompetensi PNS. Untuk mengatasi hal ini, otoritas yang dimiliki BKD selaku perangkat daerah yang membidangi kepegawaian harus diperkuat, baik oleh PPK maupun PyB, sehingga proses promosi dan mutasi tidak harus berdasarkan usulan atau rekomendasi pimpinan.

Tantangan yang dihadapi dalam proses promosi dan mutasi ini adalah bagaimana menciptakan sebuah sistem manajemen karier yang kondusif. Karena promosi dan mutasi merupakan kebijakan yang menimpa setiap PNS selama masa tugasnya, maka kebijaka promosi dan mutasi merupakan salah satu penentu kualitas PNS dan organisasi pemerintah. Seorang PNS yang kompeten tidak akan dapat menunjukkan kompetensinya secara optimal apabila dalam sistem manajemen karier masih membuka kesempatan terkait dengan unsur kedekatan dan uang. Hal ini disampaikan oleh Ibu IKR sebagai berikut : 
"Jabatan apapun itu, dalam kompetisi ini sistem yang diterapkan, kebijakan yang diterapkan itu tidak kondusif Artinya apa? Masih membuka ruang gerak terkait dengan unsur kedekatan atau unsur uang. Akhirnya penempatan dalam jabatan itu menjadi ternodai, tidak idealis, tidak obyektif. Kemudian, karena seperti itu, mereka kemudian, lah percuma saya belajar, wong yang penting saya punya kedekatan dengan pimpinan. Ngapain saya yang harus mengembangkan SDM saya. Jadi banyak alasan. Akhirnya, ngapain juga saya harus belajar IT yang bertele-tele dan kadang memerlukan waktu lama."

Apalagi menurut Bapak ST, beberapa kebijakan promosi dan mutasi masih belum dilakukan berdasarkan kesesuaian kompetensi.

"Terkait promosi jabatan ini belum optimal, karena ada yang belum sesuai profesi. Idealnya harus sesuai background ijazah, kompetensinya, untuk memperlancar kinerja."

Selain masalah tersebut, transparansi menjadi suatu dilema dalam era manajemen PNS. Proses promosi dan mutasi masih dimaknai sebagai rahasia negara yang harus dijaga erat. Hanya pimpinan dan pihak-pihak terkait yang boleh mengetahu rencana promosi dan mutasi. Dilihat dari sudut pandang regulasi, kondisi seperti ini tidak dapat dibenarkan. Kondisi ini menjadi sebuah dilema karena menurut Bapak JU, tindakan ini diperlukan untuk menjaga stabilitas organisasi, agar setiap elemen organisasi tetap dapat fokus pada tugas pokok dan fungsinya dan tidak menyebabkan kegaduhan.

“... karena apa, usulan itu sifatnya rahasia, dan itu kita tidak mau membuat gaduh, kalau yang bersangkutan tau bila diusulkan itu kan otomatis gaduh. Solusinya kita menghubungi kepala perangkat daerah."
Aktivitas promosi dan mutasi sebagai bagian dalam manajemen karir telah dilaksanakan menggunakan prinsip-prinsip MSDM berbasis kompetensi meski belum menyeluruh. Hal ini ditunjukkan dalam pelaksanaan uji kompetensi yang masih terbatas dilakukan pada level top manager (Jabatan Pimpinan Tinggi). Selain itu kebijakan terkait transparansi dan ego sektoral pimpinan menjadi suatu masalah yang harus ditemukan solusinya untuk dapat melaksanakan MSDM berbasis kompetensi secara menyeluruh.

\section{Penilaian Kinerja}

Pada dasarnya MSDM berbasis kompetensi bertujuan untuk meningkatkan kinerja individu dan organisasi, dimana salah satunya melalui penilaian kinerja berbasis kompetensi yang bermanfaat untuk menyediakan informasi yang berguna bagi praktek-praktek MSDM (Azmi, 2010). Informasi-informasi ini digunakan untuk menyusun perencanaan dan strategi terkait pelatihan dan pengembangan, karir serta pembayaran kompensasi bagi karyawan dan dapat digunakan untuk menentukan keterampilan dan kompetensi karyawan secara tepat (Robbins \& Judge, 2015). Menurut Dessler (2015) manajemen kinerja memberikan peluang bagi organisasi untuk mengetahui kegagalan yang terjadi dalam sebuah organisasi, sekaligus mencari solusi atas kondisi tersebut, baik melalui strategi pelatihan maupun penempatan (Dessler, 2015). Manfaat MSDM berbasis kompetensi dalam penilaian kinerja dapat diidentifikasikan menjadi beberapa hal, yaitu pertama memberikan informasi yang lebih mendalam tentang kinerja individu, kedua memberikan alternatif solusi terhadap suatu kegagalan kinerja, misalnya melalui program pelatihan atau penempatan, ketiga sebagai informasi pelengkap terhadap hasil penilaian kompetensi, karena bisa jadi dalam aktivitas MSDM terjadi ketidaksesuaian penampatan dan pemberian tugas serta jabatan yang entah disadari atau tidak oleh bagian HRD, keempat dapat digunakan sebagai bahan pemberian gaji dan reward secara adil dan proporsional. 
Penilaian kinerja PNS di Pemerintah Kabupaten Tulungagung dilakukan melalui Sasaran Kinerja Pegawai (SKP). Model, forma dan metode penilaian memang mengacu pada ketentuan tentang SKP, akan tetapi terdapat permasalahan pada implementasi praktis. SKP disebut tetap memiliki celah yang dapat dimanfaatkan baik bagi PNS maupun pejabat penilai untuk memanipulasi penilaian. Hal ini diungkapkan saudara EC berikut ini :

"Seharusnya SKP menjadi tolok ukur kinerja PNS, namun faktanya, SKP ternyata tetap terdapat celah untuk dimanipulasi dan dilakukan oleh semua pihak, baik yang dinilai, penilai maupunn atasan penilai"

Kelemahan SKP menurut Ibu IKR adalah tidak adanya standar dan tolok ukur yang disepakati bersama.

"Sekarang seperti ini, SKP, sasaran kerja pegawai, pengganti DP3, apakah itu efektif? Tidak. Sebetulnya sama saja. Kenapa? Ya karena tidak ada tolak ukur yang disepakati secara bersama."

Kondisi ini menjadi suatu titik lemah dalam implementasi MSDM berbasis kompetensi di Pemerintah Kabupaten Tulungagung. Karena kompetensi seorang PNS tidak dapat dievaluasi melalui kinerja riil yang telah dia capai. Untuk mengatasi ini pada level JPT, BKD telah memberlakukan syarat administratif, sebagai "rambu-rambu" yang akan memastikan peserta uji kompetensi dan seleksi terbuka memiliki kesesuaian kompetensi. Hal ini sebagaimana disampaikan Bapak JU :

"Itu tidak pernah, karena sebelum uji kompetensi ada seleksi administrasi di prosesnya, jadi misalkan 6 orang itu berhak ikut seleksi terbuka, tapi kita seleksi administrasinya dulu, jadi bisa juga salah satu tidak lolos, tapi kebetulan kemarin semua lolos."
Selain persyaratan administratif, dilakukan pemantauan atau monitoring terhadap rekam jejak dan perkembangan kompetensi JPT tersebut. Mengingat hasil uji kompetensi yang hanya berlaku 2 (dua) tahun.

"Iya, benar. Tetap dilakukan evaluasi. Kami tetap melakukan pemantauan terhadap kinerja dan rekam jejaknya selama menjabat, selain itu hasil uji kompetensi itu hanya berlaku selama 2 tahun, setelah lewat 2 tahun harus dilakukan uji kompetensi lagi untuk mengetahui perkembangan kompetensi yang bersangkutan. Jadi bisa berkembang, bisa juga menurun"

Ketidak efektifan SKP ini memang menjadi kendala serius dalam implementasi MSDM berbasis kompetensi. Sebaik apapun aktivitas manajemen PNS yang lain, apabila kinerja seorang PNS tidak dapat diukur dengan tepat, maka sulit untuk menentukan efektifitas dari pelaksanaan MSDM berbasis kompetensi dalam manajemen PNS. Sebuah sistem penilaian yang optimal dan obyektif perlu segera dirumuskan agar tujuan manajemen PNS berdasarkan UU ASN yang berdasarkan kualifikasi, kompetensi dan kinerja dapat dicapai oleh Pemerintah Kabupaten Tulungagung.

\section{Pembahasan}

Dalam konteks tema penelitian, penelitian ini serupa dengan yang dilakukan oleh Pendit (2012) dimana penelitian tersebut mengupas implementasi CHRM pada Komisi Pemberantasan Korupsi (KPK). Pada penelitian tersebut terungkap bahwa pelaksanaan CHRM pada KPK belum dapat dilaksanakan dengan sempurna, mengingat hanya beberapa saja dari aspek MSDM yang telah tersentuh oleh prinsip CHRM.

Penelitian ini juga mengungkap hal serupa, dimana pada Pemerintah Kabupaten Tulungagung hanya proses Rekrutmen dan seleksi yang telah menerapkan prinsip CHRM, sedangkan proses Manajemen Karir dan Pelatihan serta Pengembangan Kompetensi masih melaksanakan sebagian 
prinsip CHRM, dimana masih ada aspek lain seperti kebijakan pimpinan, regulasi dan pertimbangan politis yang turut serta dalam proses tersebut. sementara pada proses Penilaian Kinerja belum tersentuh prinsip CHRM mengingat proses penilaian kinerja tidak memiliki tolok ukur yang jelas dan masih bersifat administratif saja.

\section{Kesimpulan}

Implementasi MSDM berbasis kompetensi dalam manajemen PNS ditemukan dalam proses rekrutmen dan seleksi, manajemen karier dan pengembangan kompetensi. Sedangkan dalam penilaian kinerja tidak ditemukan implementasi MSDM berbasis kompetensi, karena penilaian kinerja dilakukan oleh atasan yang dalam pelaksanaannya dilakukan tidak optimal dan efektif. Ketidakefektifan ini disebabkan tidak ada indikator, tolok ukur dan jenis pekerjaan yang disepakati bersama berikut indikator penilaiannya. Pada proses rekrutmen dan seleksi syarat-syarat kompetensi telah disebutkan secara detail sesuai ketentuan regulasi. Pada pengembangan kompetensi, prinsip MSDM berbasis kompetensi juga dilakukan dengan terbatas, kendala infrastruktur, dukungan anggaran dan persepsi dari pimpinan unit organisasi maupun PNS itu sendiri menjadi penghambat dalam pelaksanaan program pengembangan kompetensi. Sementara dalam manajemen karier implementasi MSDM berbasis kompetensi masih dilakukan secara terbatas, hal ini terkait belum dapat dilakukannya uji kompetensi secara menyeluruh serta masih adanya sedikit celah berdasarkan regulasi yang berlaku yang masih memberikan tempat terhadap hal-hal di luar aspek kompetensi, meskipun hal ini dapat diantisipasi dengan memberikan syarat administratif yang ketat.

\section{DAFTAR PUSTAKA}

-. (2016a, 25 May 2016). Kompetensi ASN Masih Hadapi Sejumlah Permasalahan. Retrieved from http://lan.go.id/id/beritalan/kompetensi-asn-masih-hadapisejumlah-permasalahan
-. (2016b, 14 October 2016). Tajuk : PNS

Dalam Sorotan Pungli dan Suap. Retrieved from http://nasional.harianterbit.com/nasional/ 2016/10/14/70463/0/25/Tajuk-PNS-

Dalam-Sorotan-Pungli-dan-Suap

-. (2017, 7 May 2017). PP 11 Tahun 2017

Ubah Manajemen PNS. Retrieved from http://www.jpnn.com/news/pp-11-tahun2017-ubah-manajemen-pns

Akbar, R. M., \& Akbar, A. (2012). Human

Resource Management Competency Model for Pakistani Banking Companies. African Journal of Business Management, 6(38), 13. Doi : 10.5897/AJBM11.2552

Androniceanu, A. (2007). New Public Management, a Key Paradigm for Reforming Public Management in Romanian Administration. Administratie si Management Public, 8, 9.

Antwi, K. B., \& Analoui, F. (2008). Reforming Public Sector : Facing the challenges of Effective Human Resource Development Policy in Ghana. Journal of Management Development, 27(6), 13. Doi : 10.1108/02621710810877848

Arundel, A., Casali, L., \& Hollanders, H. (2015). How European Public Sector Agencies Innovate : The use of Bottomup, policy-dependent and knowledgescanning innovation methods. Research Policy, 44, 12. Doi : 10.1016/j.respol.2015.04.007

Audenaert, M., Vanderstraeten, A., Buyens, D., \& Desmidt, S. (2014). Does Alignment Elicit Competency-based HRM? A Systematic Review. Management Review, 25(1), 23. Doi : 10.1688/mrev-2014-01-Audenaert

Azis, F., \& Akhtar, M. M. S. (2014). Impact of Training on Teachers Competencies at Higher Education Level in Pakistan. International Refereed Research Journal, 5(1), 9.

Azmi, I. A. G. (2010). Competency-based Human Resource Practice in Malaysian Public sector Organizations. African Journal of Business Management, 4(2), 8. 
Bingle, B. S., Meyer, C. K., \& Taylor, A. (2013). Nonprofit and Publi Sector Human Resources Management : A Comparative Analysis. International Journal of Management and Information Systems, 17(3), 29.

Bloch, C., \& Bugge, M. M. (2013). Public Sector Innovation - From Theory to Measurement. Structural Change and Economics Dynamics, 27, 13. Doi : 10.1016/j.strueco.2013.06.008

Burdett, K. (2011). Towards a Theory of Labor Market with a Public sector. Labour Economics, 19, 8. Doi : 10.1016/j.labeco.2011.07.006

Buurman, M., Delfgaaue, J., Dur, R., \& Bossche, S. V. d. (2012). Public Sector Employees : Risk Averse and Altruistic. Journal of Economic Behavior and Organization, 83, 13. Doi : 10.1016/ j.jebo.2012.06.003

Chan, D. C. (2006). Core Competencies and Performance Management in Canadian Public Libraries. Library Management, 27(3), 10. Doi : 10.1108/ 01435120610652897

Chau, D. M. (1997). Administrative Reform in Vietnam : Need and Strategy. Asian Journal of Public Administration, 19(2), 18. Doi : 10.1080/02598272.1997. 10800343

Common, R. (2011). International trends in HRM in the Public Sector : Reform Attempts in the Republic of Georgia. International Journal of Public Sector Management, 24(5), 14. Doi : 10.1108/ 09513551111147150

Creswell, J. W. (2014). Research Design, Qualitative, Quantitative, and Mixed Methods Approaches (A. Fawaid \& R. K. Pancasari, Trans. Fourth Edition ed.): Pustaka Pelajar.

Darling, S. D., \& Cunningham, J. B. (2016). Underlying Values and Competencies of Public and Private Sector Managers. Asian Education and Deveopment Studies, 5(4), 27. Doi : I 10.1108/AEDS09-2015-0050

Dessler, G. (2015). Human Resource Management, 14th ed. (D. Angelica,
Trans. 14th ed.). New Jersey: Pearson Education.

Hondeghem, A., \& Vandermeulen, F. (2000). Competency Management in the Flemish and Dutch Civil Service. The International Journal of Public Sector Management, 13(4), 12.

Peraturan Pemerintah Nomor 11 Tahun 2017 tentang Manajemen PNS, (2017).

Jackson, S. E., Schuler, R. S., \& Werner, S. (2009). Managing Human Resources, 10th ed. (B. Prihartanto, Trans. 10th ed.). Singapore: Cengage Learning Asia.

Kapucu, N. (2009). New Public Management and Governance Perspectives in Understanding Public Management. Pulilc Administration Review, 69(6), 4.

Khan, J., \& Charles-Soverall, W. (1993). Human Resource Development in the Public Sector: A Developing Country Experience. The International Journal of Public Sector Management, 6(1), 11.

Moeheriono. (2014). Pengukuran Kinerja Berbasis Kompetensi (2nd ed.). Jakarta: Rajawali Pers.

Philippidou, S. S., Soderquist, K. E., \& Prastacos, G. P. (2004). Towards New Public Management in Greek Public Organizations : Leadership vs Management, and the Path to Implementation. Public Organization Review, 4, 22.

Ridder, H.-G., \& Hoon, C. (2009). Introduction to the Special Issue : Qualitative Methods in Research on Human Resource Management. Zeitschrift fur Personalforschung, 23(2), 14. Doi : $10.1688 / 1862-$ 000_ZfP_2009_02_Ridder

Robbins, S. P., \& Judge, T. A. (2015). Organizational Behavior (R. Saraswati $\&$ F. Sirait, Trans. 16th ed.). New Jersey: Pearson Education.

Rochmi, M. N. (2017, 7 June 2017). Mayoritas PNS Tak Punya Keahlian Khusus. Retrieved from https://beritagar. $\mathrm{id} /$ artikel/berita/mayoritas-pns-takpunyakeahlian-khusus

Saleh, C., Islamy, M. I., Zauhar, S., \& Supriyono, B. (2013). Pengembangan 
Kompetensi Sumberdaya Aparatur (1st ed.). Malang: UB Press.

Scharitzer, D., \& Korunka, C. (2000). New Public Management : Evaluating the Success of Total Quality Management and Change Management Interventions in Public Services from the Employees and Costumers Perspectives. Total Quality Management, 11(7), 13.

Sedarmayanti. (2016). Manajemen Sumber Daya Manusia, Reformasi Birokrasi dan Manajemen Pegawai Negeri Sipil (D. Sumayyah Ed. 2nd Edition ed.). Bandung: Refika Aditama.

Sensuse, D. I., Cahyaningsih, E., \& Wibowo, W. C. (2015). Identifying Knowledge Management Process of Indonesian Government Human Capital Management using Analytical Hierarchy Process and Pearson Correlation Analysis. Procedia Computer Science, 72, 11. Doi : 10.1016/j.procs.2015. 12.136

Setiyono, B. (2014). Pemerintahan dan Manajemen Sektor Publik (T. Admojo Ed.). Yogyakarta: CAPS.

Shen, H., Zhong, S., \& Chen, R. (2016). Span and Scale of the Government : analysis of the Public Personnel Reform in Environmental Regulation Sectors. Public Personnel Management, 45(1), 12. Doi : $10.1177 / 0091026016630400$

Siugzdiniene, J. (2006). Competency Management in the Context of Public Management Reform. Viesoji Politika ir Administravimas(18), 9.

Spencer, L. M., \& Spencer, S. M. (1993). Competence at Work : Models for Superior Performance (pp. 392). Retrieved from onlinelibrary.org database Retrieved from http://openlibrary.org/books/OL2232216 5M/Competence_at_work

Sukmadilaga, C., Pratama, A., \& Mulyani, S. (2015). Good Governance Implementation in Public Sector : Exploratory Analysis of Government Financial Statements Disclosures Across ASEAN Countries. Procedia-Social
Behavioral Sciences, 211, 6. Doi : 10.1016/j.sbspro.2015.11.068

Thoha, M. (2016). Manajemen Kepegawaian Sipil di Indonesia (2nd ed.). Jakarta: Prenamedia Group.

Wahyuni, S. (2012). Qualitative Research Method : Theory and Practice (D. A. Halim Ed. Vol. 1). Jakarta: Salemba Empat.

Yin, R. K. (2011). Qualitative Research from Start to Finish. New York: The Guilford Press. 